\title{
Calcium-mediated Postharvest Changes in Texture and Cell Wall Structure and Composition in ‘Golden Delicious' Apples
}

\author{
Gregory M. Glenn'and B.W. Poovaiah ${ }^{2}$ \\ Department of Horticulture and Landscape Architecture, Washington State University, Pullman, \\ WA 99164-6414
}

\begin{abstract}
Additional index words. electron microscopy, quality, Malus domestics, X-ray microanalysis, tensile strength
Abstract. Changes in texture, cell wall structure and composition during storage of Ca-treated and untreated 'Golden Delicious' apple fruit (Malus domestics Borkh.) were investigated. The cell wall region of Ca-treated fruit showed no swelling during storage and cell-to-cell contact was maintained, whereas regions of the middle lamella in untreated tissue stained lightly, appeared distended, and eventually separated. In control fruit, microfibril orientation was lost in distended regions of the cell wall, especially in the outer wall region adjacent to the middle lamella. Furthermore, the middle lamella was fenestrated and in some cases was completely degraded. These changes during storage of control fruit were accompanied by a decrease in arabinose and galactose moieties of the cell wall and an increase in soluble pectin. Calcium treatment of fruit inhibited solubilization of polyuronide and arabinose moieties and reduced the loss in galactose content during storage. Tensile strength and firmness were positively correlated to Ca content of the fruit cortex. Excessive tensile stress caused tissue failure in control fruit when cells of the cortical tissue separated at the middle lamella. In contrast, cylinders of Ca-treated fruit fractured through cortical cell walls.
\end{abstract}

Firmness in apple fruit is an important quality criterion that is used to determine storability. Firmness is largely determined by cell wall composition and structure (Mohsenin, 1970). Loss of textural quality in apple is a growing concern for the apple industry since daminozide use has stopped. These concerns have rekindled an interest in understanding and manipulating changes that lead to apple fruit softening.

Major changes occurring in cell wall composition of senescing apple fruit have been well-characterized (Takavoli and Wiley, 1968; Knee, 1973; Bartley, 1974). These changes include a decrease in galactose and arabinose moieties of the water-insoluble cell wall fraction followed by an increase in soluble polyuronide (Knee, 1973; Bartley, 1974). Calcium, an important constituent of the cell wall, interacts with pectic polymers and modifies cell wall strength (Dey and Brinson, 1984; Grant et al., 1973). Increasing $\mathrm{Ca}$ content of apple fruit through $\mathrm{Ca}$ treatments reduces the rate of softening (Mason, 1976; Betts and Bramlage, 1977; Scott and Wills, 1977; Johnson, 1979) and decreases pectin solubilization (Sams and Conway, 1984). The effect of $\mathrm{Ca}$ on other changes in cell wall composition is less well-understood.

Changes in cell wall structure would be expected to closely parallel changes in cell wall composition and fruit texture (Mohsenin, 1970). Relatively little is known about structural changes of cortical cell walls of apple fruit during ripening and senescence and the influence of $\mathrm{Ca}$ on these changes (Mahanty and Fineran, 1975; Fuller, 1976; Ben-Arie and Kislev, 1979), possibly because postharvest changes in the structure of apple cell wall are not very pronounced compared to the changes in other fruit (Knee, 1973). In an innovative study of texture in apple

Received for publication 12 Sept. 1989. Scientific Paper no. 7969, College of Agriculture and Home Economics Research Center, Washington State Univ., Pullman, Wash. This work was supported in part by the Washington State Tree Fruit Commission and the National Science Foundation Grant DCB-8801860 to BWP. The cost of publishing this paper was defrayed in part by the payment of page charges. Under postal regulations, this paper therefore must be hereby marked advertisement solely to indicate this fact.

'Current address: 800 Buchanan Street, WRRC-ARS, USDA, Albany, CA 94710. Professor. Dept. Horticulture and Landscape Architecture, Washington State Univ., Pullman, WA 99164-6414. and potato, Diehl and Hamann (1979) used SEM to relate structural properties of the cortical tissue to texture. Here we report the use of various analytical techniques, including microscopy, to characterize the influence of $\mathrm{Ca}$ treatments on postharvest changes in texture, cell wall structure, and cell wall composition in 'Golden Delicious' apple fruit.

\section{Materials and Methods}

'Golden Delicious' apples were obtained from the horticulture orchards of Washington State Univ. in Pullman, and were stored at $2 \mathrm{C}$ for 2 days. Four replicates of 20 fruit each were dipped in deionized water (control) or infiltrated with a cold (2C) $\mathrm{CaCl}_{2}$ (4\% w/v) solution (Poovaiah and Moulton, 1982) for 2 rein, using a combination of vacuum $(-28 \mathrm{kPa})$ and pressure $(28$ $\mathrm{kPa}$ ). The fruit were then rinsed and treated with a fungicide containing benomyl before being stored at $2 \mathrm{C}$.

Tension test. Fruits were removed from storage 6 months after harvest and equilibrated to room temperature $(3 \mathrm{hr})$. The fruits were cored before we took samples for measurement. Samples were prepared similar to the methods of Diehl and Hamann (1979). Cylinders of tissue were cut using a specially designed cork borer. A groove was cut around the cylinder to a depth of $3 \mathrm{~mm}$ and a distance of $10 \mathrm{~mm}$ from the peel using a lathe constructed for that purpose. Each half of the cylinder was then attached to opposing clamps installed on a recording laboratory penetrometer (Topping, 1981). The upper and lower clamps were mounted on the deflection beam and the motor-driven platform, respectively. The transducer probe was loaded and calibrated in the range of preliminary samples to register the downward deflection of the beam during tension tests. The force required to pull the tissue cylinder into two halves was recorded. Penetrometer measurements were performed as described by Topping (1981). Cylinders of cortical tissue were removed from a site adjacent to where the penetrometer probe had been inserted and were saved for Ca analysis. Tissue cylinders were forced air-dried (80C) for $48 \mathrm{hr}$, ashed, and analyzed by atomic absorption spectrophotometry for $\mathrm{Ca}$ content following standard procedures (Ferguson et al., 1979).

Microscopy. Tissue blocks $\left(2 \mathrm{~mm}^{2}\right)$ were cut $=4 \mathrm{~mm}$ below the peel and placed in primary fixative (3\% glutaraldehyde in 
$0.1 \mathrm{M}$ phosphate buffer, $\mathrm{pH}$ 7.2) for $3 \mathrm{hr}$. The tissue was rinsed in phosphate buffer and postfixed for $6 \mathrm{hr}$ in $1 \% \mathrm{OsO}_{4}$ and 50 $\mathrm{mM}$ phosphate buffer. The tissue was dehydrated in a graded ethanol series, infiltrated with Spurr's resin, and polymerized at $60 \mathrm{C}$. Sections $(2 \mu \mathrm{m})$ were cut with a glass knife by use of a Reichert OM-U2 ultramicrotome. The sections were placed on glycerol-coated glass slides and stained with Stevenel's blue (Ridgeway, 1986). Photomicrographs were made using a compound photomicroscope (Olympus model PM1OAD).

Ultrathin sections were cut with glass knives by means of a Reichert OM-U2 ultramicrotome and then mounted on formvarcoated copper grids. The sections were stained with uranyl acetate and Reynold's lead citrate before viewing. Transmission electron micrographs were taken using a Hitachi HS8 transmission electron microscope.

For scanning electron microscopy, tension-tested cylinders of tissue were fixed and dehydrated as described above. The dehydrated samples were critical point-dried and gold-coated (10 rim). Scanning electron micrographs of the fractured surface of tension-tested samples were produced using an ETEC Autoscan (Electron Beam Technology/Perkin-Elmer, Hayward, Calif). The accelerating voltage was set at $20 \mathrm{kV}$. Scanning electron micrographs of frozen, gold-coated samples were taken on a Hitachi S800 field emission SEM equipped with a cold stage and operated with an accelerating voltage of $5 \mathrm{kV}$.

Calcium localization. Tissue blocks $\left(2 \mathrm{~mm}^{2}\right)$ were excised 3 $\mathrm{mm}$ below the peel of fruit that had been stored 3 months and were immediately frozen in liquid $\mathrm{N}_{2}$. The samples were allowed to equilibrate to $-2 \mathrm{QC}$ before they were sectioned (100 $\mu \mathrm{m})$ with a sliding microtome. Attempts to make thinner sections of tissue were unsuccessful due to a lack of tissue cohesion. The frozen sections were mounted on carbon stubs, placed in a desiccator packed in dry ice, and freeze-dried. The samples were carbon coated and viewed using an ETEC Autoscan scanning electron microscope. A UNISPEC 7000 system (KEVEX, Burlingame, Calif.) was used to construct an element map of the $\mathrm{Ca}$ distribution within the freeze-dried samples.

Cell wall preparation. Cortical tissue $(100 \mathrm{~g})$ from four fruit was frozen and prepared as described by Ahmed and Labavitch (1980). The frozen tissue was homogenized in three volumes of cold $(3 \mathrm{C})$, distilled $\mathrm{H}_{2} \mathrm{O}$ for $2 \mathrm{~min}$ in a Waring blender. Following centrifugation (Sorvall model RC5B) of the brei for $10 \mathrm{~min}$ at $10,000 \times \mathrm{g}$ in a SS34 rotor (4C), the pelleted material was washed twice with cold, distilled water. The supernatant and wash solutions (soluble fraction) were combined and frozen for later use.

The pellet was washed twice each in $100 \mathrm{mM}$ and $500 \mathrm{mM}$ $\mathrm{K}$-phosphate buffer ( $\mathrm{pH}$ 7.0) followed by four washes in distilled $\mathrm{H}_{2} \mathrm{O}$. The pellet was washed in 1 chloroform $: 1$ methanol (v/v) and filtered in a sintered glass funnel. Following three washes in chloroform-methanol, the pellet was washed three times in acetone, air dried, and stored in a vacuum oven at 50C. Four replicates of each treatment were prepared for cell wall analysis.

Cell wall analysis. A 10-mg sample of the cell wall preparation was washed three times in $50 \mathrm{mM}$ Na-phosphate buffer before enzymatic starch extraction as described by Kato and Nevins (1984). The cell wall was suspended in $10 \mathrm{ml}$ of $50 \mathrm{mM}$ Na-phosphate buffer ( $\mathrm{pH}$ 6.9) and incubated with $\quad-\alpha$-amylase $(0.0125 \mathrm{mg}$ protein $/ \mathrm{ml}$ ) from porcine pancreas (Sigma, St. Louis) for $48 \mathrm{hr}$ at $25 \mathrm{C}$ with continuous agitation. A drop of toluene was added to inhibit microbial growth. After incubation, the samples were centrifuged at $10,000 \mathrm{x}$ g for $10 \mathrm{~min}$. One mil- liliter of the supernatant was assayed calorimetrically for hexose as described by Updegraff (1969) using anthrone. The cell wall samples were washed extensively with distilled water until no hexose could be detected in the washings.

The pelleted wall material was dried at 60C under a stream of filtered air. Two milliliters of $2 \mathrm{~N}$ trifluoroacetic acid (TFA) containing myo-inositol $(1 \mathrm{mg})$ as an internal standard were added to the dried wall material (Albersheim et al., 1967). The tubes were sealed with teflon caps and hydrolyzed for $1 \mathrm{hr}$ at $121 \mathrm{C}$ in a steam autoclave. The supernatant and three distilled $\mathrm{H}_{2} \mathrm{O}$ washes were transferred to a clean test tube (TFA-soluble material) and evaporated to dryness at $60 \mathrm{C}$ under a stream of filtered air. The TFA-insoluble material was analyzed according to Blakeney et al. (1983) and found to contain no detectable levels of sugars other than glucose. The TFA-insoluble material was hydrolyzed and quantified as described earlier (Ahmed and Labavitch, 1980; Updegraff, 1969) using glucose as a standard.

The TFA-soluble sugars were reduced and acetylated as described by Blakeney et al. (1983) and analyzed by gas liquid chromatography. Gas liquid chromatography was performed using a Packard model 427 gas chromatography equipped with flame ionization detectors and fitted with dual glass columns $(0.2 \mathrm{x}$ $190 \mathrm{~cm}$ ) packed with 3\% SP2340 (Supelco). Separations were achieved with a N-flow rate of $30 \mathrm{ml}$ "rein-1 with the oven at 210C. The detector response was recorded using a Linear Instruments (model 255/MM, Irvine, Calif.) chart recorder. Peak identification was determined by co-chromatography against standards, and peak area was obtained using the cut-and-weigh method.

Water-soluble pectin was precipitated from the water-soluble fraction using aliquots $(15 \mathrm{ml})$ of each of the four replicates per treatment. The pectin content was quantified as described by Blumenkrantz and Asboe-Hansen (1973). The water-insoluble pectin content of the cell wall was estimated in cell wall samples (5 mg) from each of four replicates per treatment using a destructive method described by Ahmed and Labavitch (1977).

\section{Results and Discussion}

Infiltration treatments provide a rapid and effective postharvest method for increasing the Ca content of apple fruit (Scott and Wills, 1977; Johnson, 1979; Poovaiah and Moulton, 1982). However, core flooding in open-calyx fruit (Scott and Wills, 1977) and treatment-related injury of cortical tissue in some cultivars (Johnson, 1979) has limited the commercial use of infiltration treatments. We generally observed that a combination of low vacuum/pressure infiltration of chilled $\mathrm{CaCl}_{2}$ solutions into chilled fruit resulted in adequate $\mathrm{Ca}$ uptake (Figs. 1 and 2) and reduced treatment-related damage. However, a separate study designed to compare fruit damage associated with different infiltration techniques was not conducted.

Ca-treated fruit were firmer and had greater tensile strength than untreated fruit. Values obtained from tension tests gave a slightly higher correlation to levels of tissue $\mathrm{Ca}$ than did values from pressure measurements (Figs. 1 and 2). This was not surprising, since $\mathrm{Ca}$ analysis of tension-tested samples was performed using the test sample itself.

A considerable range in Ca content among cylinders of tissue excised from Ca-treated fruit was evident in Figs. 1 and 2. The average difference in $\mathrm{Ca}$ content within samples from the same fruit was $568 \mathrm{ppm}(\mathrm{n}=20)$. The uneven $\mathrm{Ca}$ distribution resulted in a mottled appearance in some fruit, possibly due to variable rates in chlorophyll degradation (Ferguson, 1984). While some redistribution of $\mathrm{Ca}$ must occur after infiltration (Betts and 


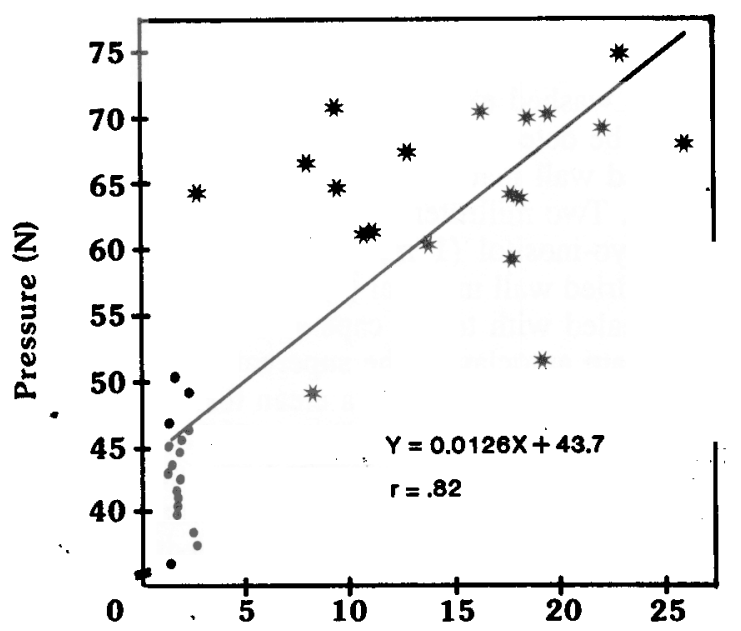

Calcium Concentration (ug/g $\times \mathbf{1 0}^{-2}$ )

Fig. 1. Correlation between Ca concentration of apple flesh and tissue firmness. Calcium analysis was performed using tissue cylinders extracted adjacent to the site tested for firmness $(\bullet=$ control, $*=$ Ca-treated)

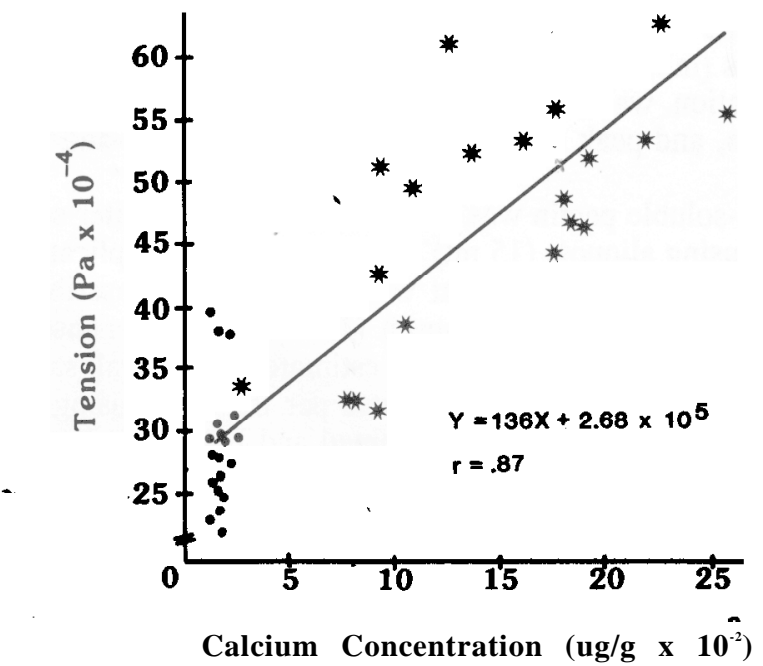

Fig. 2. Correlation between Ca concentration of apple flesh and tensile strength $(\bullet=$ control, $*=$ Ca-treated $)$.

Bramlage, 1977), our results indicated that large Ca gradients persisted within the fruit several months after treatment.

The presence of Ca-ATPases located on the plasma membrane, tonoplast, and endoplasmic reticulum provides a mechanism for possible redistribution of Ca reserves at the cellular level (Poovaiah and Reddy, 1987). The cellular distribution of $\mathrm{Ca}$ was first studied in freeze-dried sections of cortical tissue prepared using a cryostat. As expected, less structural preservation was maintained in the freeze-dried section (Fig. 3A) than in chemically fixed tissue (not shown). Nevertheless, the cell wall region and intracellular space were visible. An element map of the Ca distribution was constructed in efforts to localize the site of $\mathrm{Ca}$ action in maintaining fruit firmness. Only in $\mathrm{Ca}-$ infiltrated fruit were $\mathrm{Ca}$ reserves sufficient to construct an element map for $\mathrm{Ca}$ (Fig. 3B). A strong Ca signal (indicated by white dots) developed in regions corresponding to the cell wall (compare Fig. $3 \mathrm{~A}$ and $\mathrm{B}$ ). These results tend to confirm the role of the cell wall as a $\mathrm{Ca}$ store and the importance of $\mathrm{Ca}$ cell wall interaction in maintaining firmness.

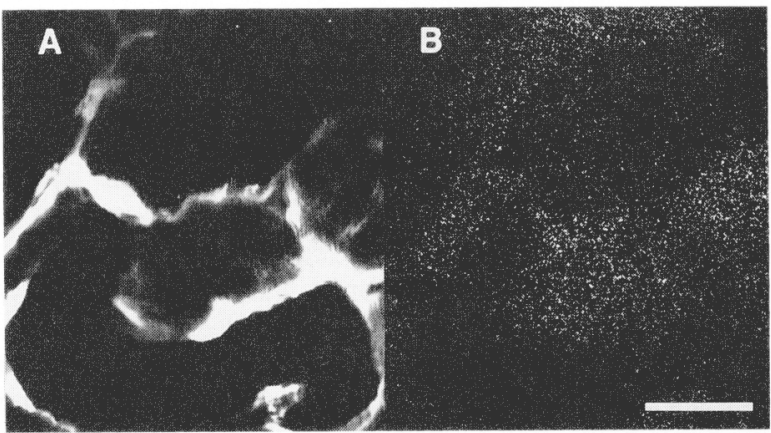

Fig. 3. (A) Scanning electron micrograph of a freeze-dried section of apple tissue 3 months following infiltration treatment. The section was prepared from frozen tissue using a cryostat. The cell wall and intracellular regions are visible even-though the ultrastructure was not well-preserved. (B) Element map of the distribution of $\mathrm{Ca}$ (white dots) corresponding to the SEM image in (A\}: Note the dense $\mathrm{Ca}$ signal distributed along the cell wall structure. Resolution of the intracellular $\mathrm{Ca}$ distribution was poor due to the lack of ultrastructural preservation and to the weak $\mathrm{Ca}$ signal, which was near background levels. Scale bar $=50 \mathrm{pm}$.

Table 1. Influence of $\mathrm{Ca}$ on changes in acidic sugar content of the cell wall during senescence in 'Golden Delicious' apple fruit.

\begin{tabular}{cccc}
\hline \hline $\begin{array}{c}\text { Duration } \\
\text { of storage } \\
\text { (months) }\end{array}$ & Ca & & \multicolumn{2}{c}{$\begin{array}{c}\text { Acidic sugar content of cell } \\
\text { wall }\left(\mathrm{mg}^{-1} \mathrm{~g}^{-1}\right.\end{array}$} & fresh wt) \\
\cline { 2 - 4 } & Soluble & Insoluble \\
\hline 0 & - & $0.27 \mathrm{a}$ & $6.00 \mathrm{a}$ \\
3.5 & - & $0.98 \mathrm{~b}$ & $5.50 \mathrm{~b}$ \\
7 & - & $1.06 \mathrm{~b}$ & $5.30 \mathrm{~b}$ \\
7 & + & $0.27 \mathrm{a}$ & $5.90 \mathrm{a}$ \\
\hline
\end{tabular}

${ }^{2}$ Mean separation in columns by Duncan's multiple range test, $P=$ 0.05 .

Redistribution of cellular Ca reserves may occur during freezedrying. Therefore, attempts were also made to construct a $\mathrm{Ca}$ map from frozen-hydrated tissue. Although a significant $\mathrm{CaKa}$ signal was detected in the intercellular region of frozen, hydrated tissue, the signal/background ratio was too low to construct an element map for Ca.

Changes in acid sugar content expressed as galacturonic acid are shown in Table 1. A marked increase in the soluble pectin fraction occurred during the first 3.5 months of storage in control fruit. No significant increase in soluble pectin was observed during subsequent storage. Calcium-infiltrated fruit that remained firm during storage had no significant increase in soluble pectin concentration even after 7 months of cold storage. This result supports earlier ones that soluble polyuronide content in softening apple was negatively correlated to $\mathrm{Ca}$ concentration (Sams and Conway, 1984).

Changes occurring in neutral carbohydrates during fruit senescence are shown in Table 2. The major change observed in glucose content during storage was due to starch breakdown. Starch reserves were depleted by 3.5 months of cold storage in both Ca-treated and control fruit. Arabinose and galactose content of control fruit dropped significantly during the first 3.5 months of storage and decreased moderately thereafter (Table 2). Galactose content of the cell wall in Ca-treated fruit had decreased by 7 months of cold storage but remained higher than the control. No significant change in arabinose content occurred during storage of Ca-treated fruit. These results showed that 
Table 2. Influence of $\mathrm{Ca}$ on changes in neutral sugar content of cell wall during senescence in 'Golden Delicious' apple fruit.

\begin{tabular}{cccccccc}
\hline \hline \multirow{2}{*}{$\begin{array}{c}\text { Duration } \\
\text { of storage } \\
\text { (months) }\end{array}$} & & \multicolumn{6}{c}{ Neutral sugar content of cell wall (mg.g ${ }^{-1}$ fresh wt)z,y } \\
\cline { 2 - 7 } & Carabinose & Xylose & Galactose & Glucose & $\begin{array}{c}\text { Glucose } \\
\text { (starch) }\end{array}$ & $\begin{array}{c}\text { Glucose } \\
\text { (cellulose) }\end{array}$ \\
\hline 0 & - & $1.30 \mathrm{a}$ & $0.58 \mathrm{a}$ & $1.45 \mathrm{a}$ & $0.34 \mathrm{a}$ & $0.63+0.27$ & $4.76 \mathrm{a}$ \\
3.5 & - & $0.95 \mathrm{~b}$ & $0.56 \mathrm{a}$ & $0.91 \mathrm{c}$ & $0.36 \mathrm{a}$ & $\mathrm{ND}^{\mathrm{x}}$ & $5.05 \mathrm{a}$ \\
7 & - & $0.81 \mathrm{C}$ & $0.56 \mathrm{a}$ & $0.78 \mathrm{C}$ & $0.33 \mathrm{a}$ & $\mathrm{ND}$ & $4.62 \mathrm{a}$ \\
7 & + & $1.20 \mathrm{a}$ & $0.55 \mathrm{a}$ & $1.19 \mathrm{~b}$ & $0.34 \mathrm{a}$ & $\mathrm{ND}$ & $4.94 \mathrm{a}$ \\
\hline
\end{tabular}

${ }^{z}$ Means separation in columns by Duncan's multiple range test, $\boldsymbol{P}=0.05$.

${ }^{y}$ Rhamnose and fucose peaks overlapped and could not be estimated reliably. Nevertheless, peak heights and combined peak areas for rhamnose and fucose remained constant during senescence. A portion of the sample having a small peak of constant area that co-eluted with mannose was observed in all samples.

'ND $=$ not detectable.

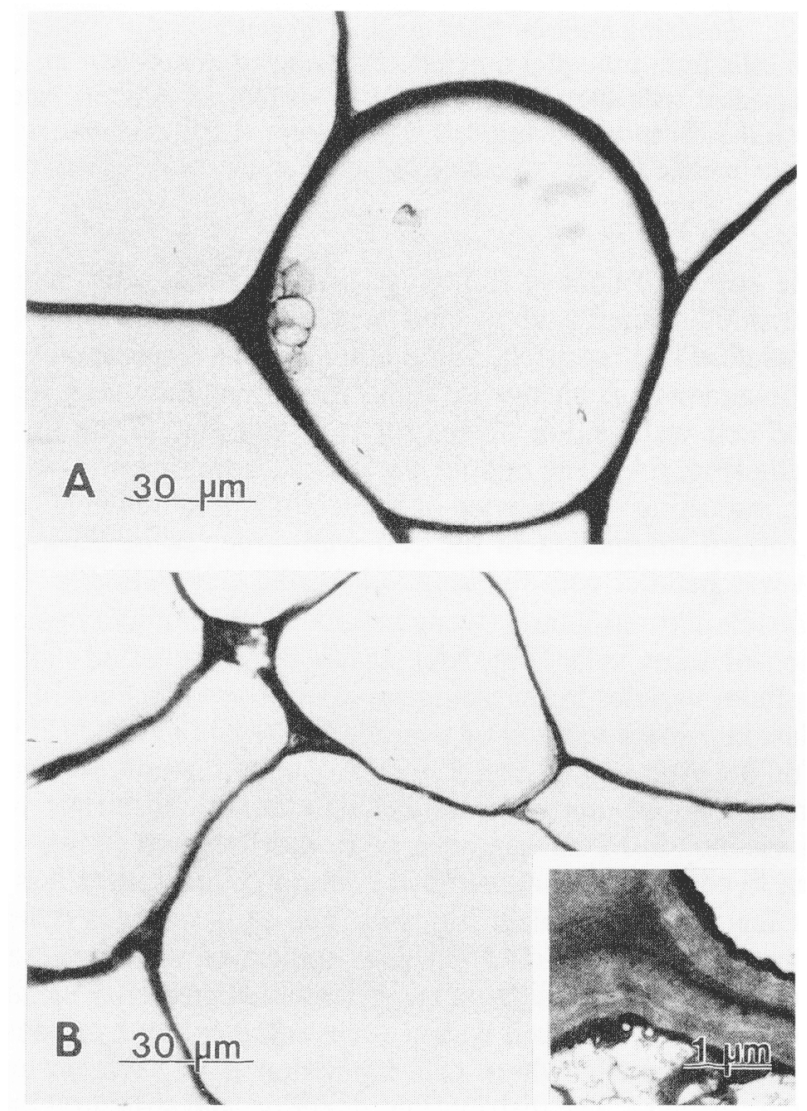

Fig. 4. Photomicrographs of sections of apple tissue from untreated fruit at harvest (A) or Ca-treated fruit after 6 months of cold (4C) storage (B). Note the large area of cell-to-cell contact. Sections are stained using Stevenel's blue. (Insert) Transmission electron micrograph of the cell wall region of Ca-treated fruit. The cell wall and middle lamella appear well-preserved.

galactose was rendered soluble in the presence of elevated $\mathrm{Ca}$ levels but at a reduced rate.

Two general mechanisms have been suggested to account for the influence of $\mathrm{Ca}$ on postharvest changes in apple texture (Ferguson, 1984). One mechanism pertains to the subtle effects of $\mathrm{Ca}$ on cellular components other than the cell wall, i.e., membranes and membrane and cell wall proteins (Brady, 1987; Glenn et al., 1988). The second mechanism is based solely on Ca-cell wall interaction (Grant et al., 1973; Brady, 1987; Fry,

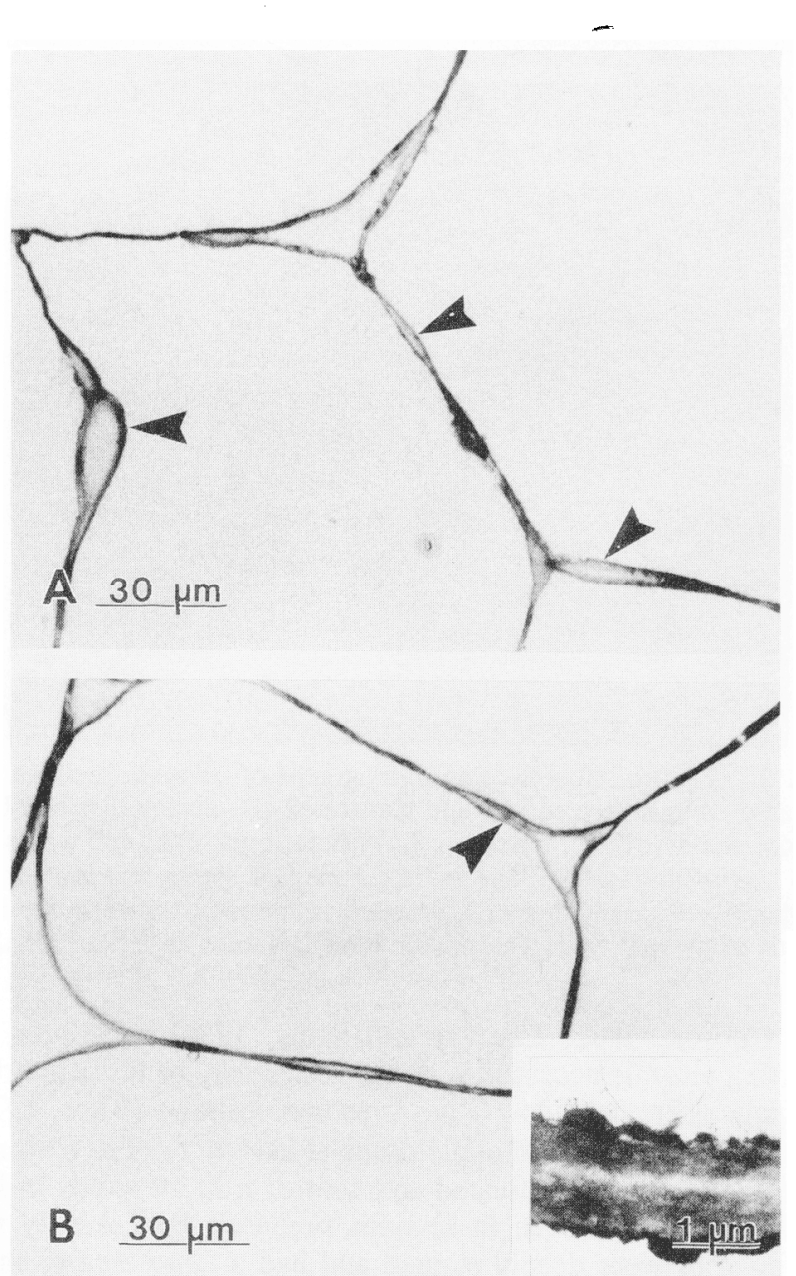

Fig. 5. Photomicrographs of sections of apple tissue from untreated fruit following 6 months of cold (4C) storage (A, B). The sections are stained with Stevenel's blue. Areas of the cell wall appear swollen and are separating (arrows). (Insert) Transmission electron micrograph of the cell wall region of tissue from untreated fruit. The cell wall and middle lamella appear partially degraded.

1986). The ability of Ca to cross-link pectic polymers of the cell wall becomes a dominant factor when $\mathrm{Ca}$ levels in the fruit are substantially increased (Brady, 1987). Extensive cross-linking may facilitate packing of pectic polymers and form a cell wall network that increases mechanical strength (Dey and Brinson, 1984) and restricts access to hydrolytic enzymes (Buescher 

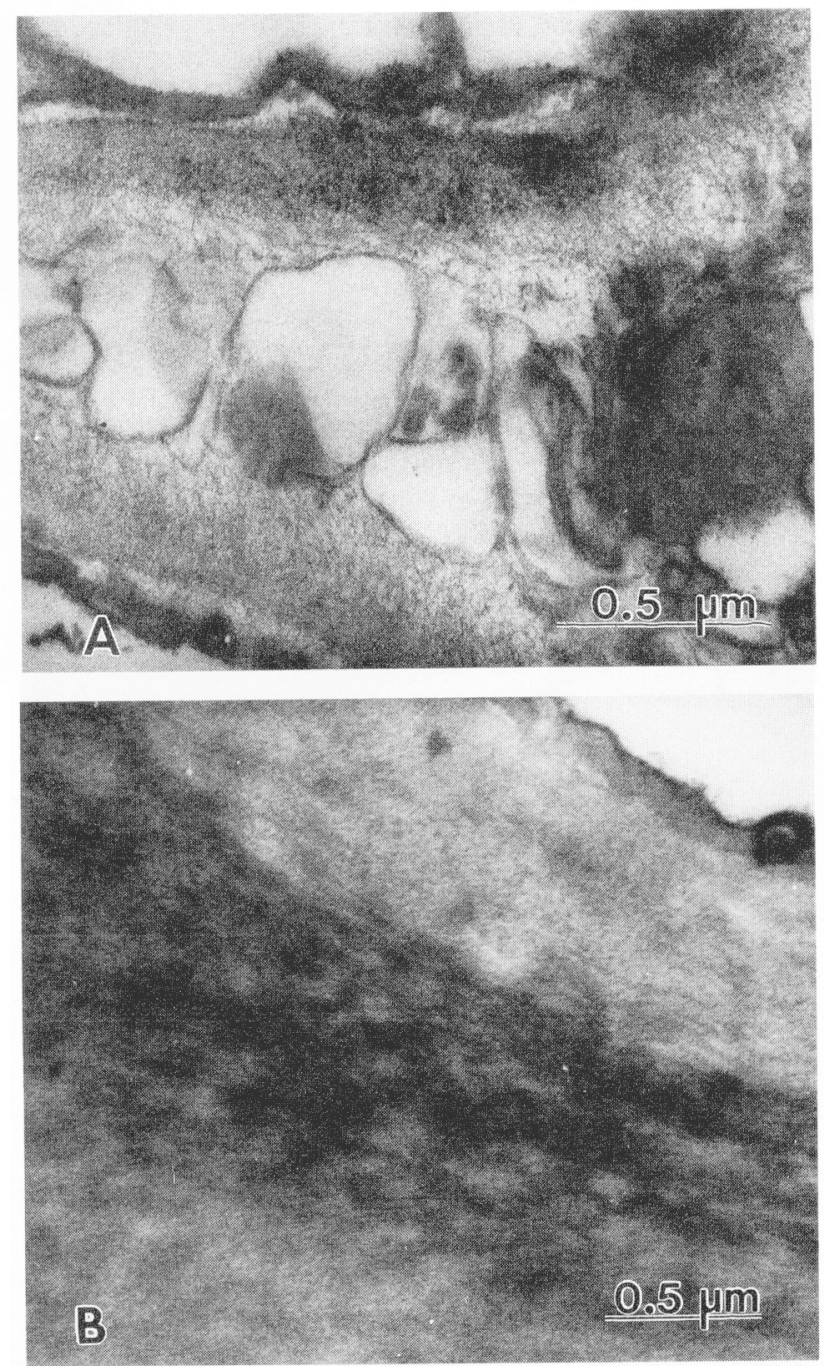

Fig. 6. Transmission electron micrographs of ultrathin sections prepared from untreated (A) and Ca-treated (B) apples that had been cold-stored (4C) for 6 months. (A) Microfibrils of the cell wall show a loss of orientation. The middle lamella appears fenestrated. (B) Microfibril orientation of Ca-treated fruit runs parallel to the long axis of the cell wall. The middle lamella shows no fenestration.

and Hobson, 1982; Conway and Sams, 1984). However, restricting enzyme access to wall substrates maybe less important in apple where no endo-PG has been demonstrated (Knee, 1973).

Light micrographs of apple tissue at harvest or after 6 months of cold storage of Ca-treated and control fruit are given in Fig. 4. The cell walls seen in sections prepared from freshly harvested fruit were deeply stained and had a large area of intercellular contact (Fig. 4A). After 6 months of storage, the cell wall of Ca-treated fruit still had a large area of cell-to-cell contact but stained less intensely (Fig. 4B). TEM micrographs of the cell wall showed that $\mathrm{Ca}$ effectively preserved the structural integrity of the middle lamella (Fig. 4, insert). Sections of tissue from untreated fruit had lightly stained cell walls that appeared distended. Cell wall separation occurred in these regions and progressed along the middle lamella (Fig. $5 \mathrm{~A}$ and B). Visible cell wall degradation occurred primarily in the middle lamella (Fig. 5, insert).

Most of the cell wall changes appeared to involve the middle lamella. Therefore, changes in this region were further studied using TEM. Visible degradation of the middle lamella occurred

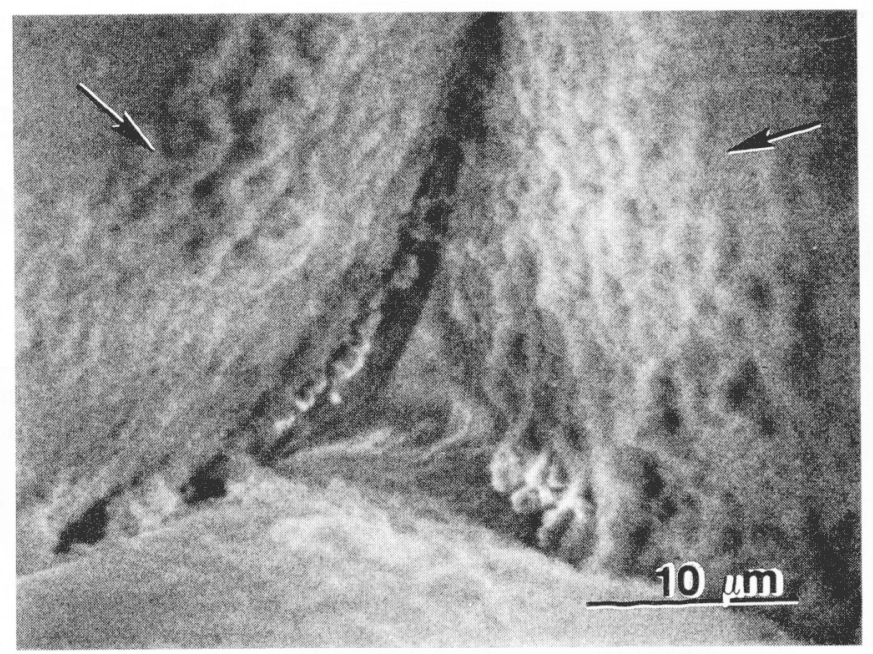

Fig. 7. Scanning electron micrograph of frozen-hydrated cortical apple cells from fruit after 6 months of storage. Extracellular material associated with the middle lamella is visible. Strands of material span the distance between cell walls except at the extreme regions of the middle lamella where cell separation may have occurred (arrows).

in the cortex of control fruit (Fig. 6A). In some cells, regions of the middle lamella were fenestrated, suggesting that extensive degradation had occurred, while other regions showed only minor breakdown. A change in microfibril orientation was visible in the cell wall region of control fruit adjacent to the middle lamella (Fig. 6A). The middle lamella of Ca-treated fruit stained dark, indicating the presence of intercellular material (Fig. 6B). Microfibril orientation in the cell wall structure of Ca-treated fruit was parallel with the long axis of the cell wall (Fig. 6B).

Vesicle-like structures were visible in the middle lamellar region of some cells (Fig. 6A). It has been suggested that extracellular vesicles in senescing apple maybe extensions of protoplasm into space vacated by degraded cell wall material (Fuller, 1976; Bel-Arie and Kislev, 1979). Although the middle lamella seen in Fig. 6A appeared degraded, cell wall materials were still visible. SEM micrographs of frozen-hydrated tissue were taken to compare the undisturbed features of the middle lamella with features observed in Fig. 6A. The cell wall was covered with extracellular material that was associated with the middle lamella (Fig. 7). Strands of the extracellular material spanned the distance between cell walls except at the extreme regions of the middle lamella where cell separation may have occurred (Fig. 7, arrows). The distribution, quantity, and structural properties of the extracellular material suggest that the vesicles are formed by cell wall rather than membrane substances.

The extracellular vesicles seen in TEM micrographs could have been formed by strands of cell wall material or may also have been an artifact of fixation. The extracellular material appeared disrupted in SEM micrographs of fixed tissue (Fig. 8C) when compared to frozen-hydrated tissue (Fig. 7). Disruption of the natural structure of the middle lamella may occur during fixation procedures for TEM and could account for inconsistencies observed in cell wall studies of softening apple.

The recording laboratory penetrometer (Topping, 1981) was effective in recording both pressure and tension forces. Visual inspection of tissue following texture measurements using SEM provided a unique system for directly relating textural properties to cell structure. The surface characteristics of the fraetured region of tension-tested samples revealed striking differences 

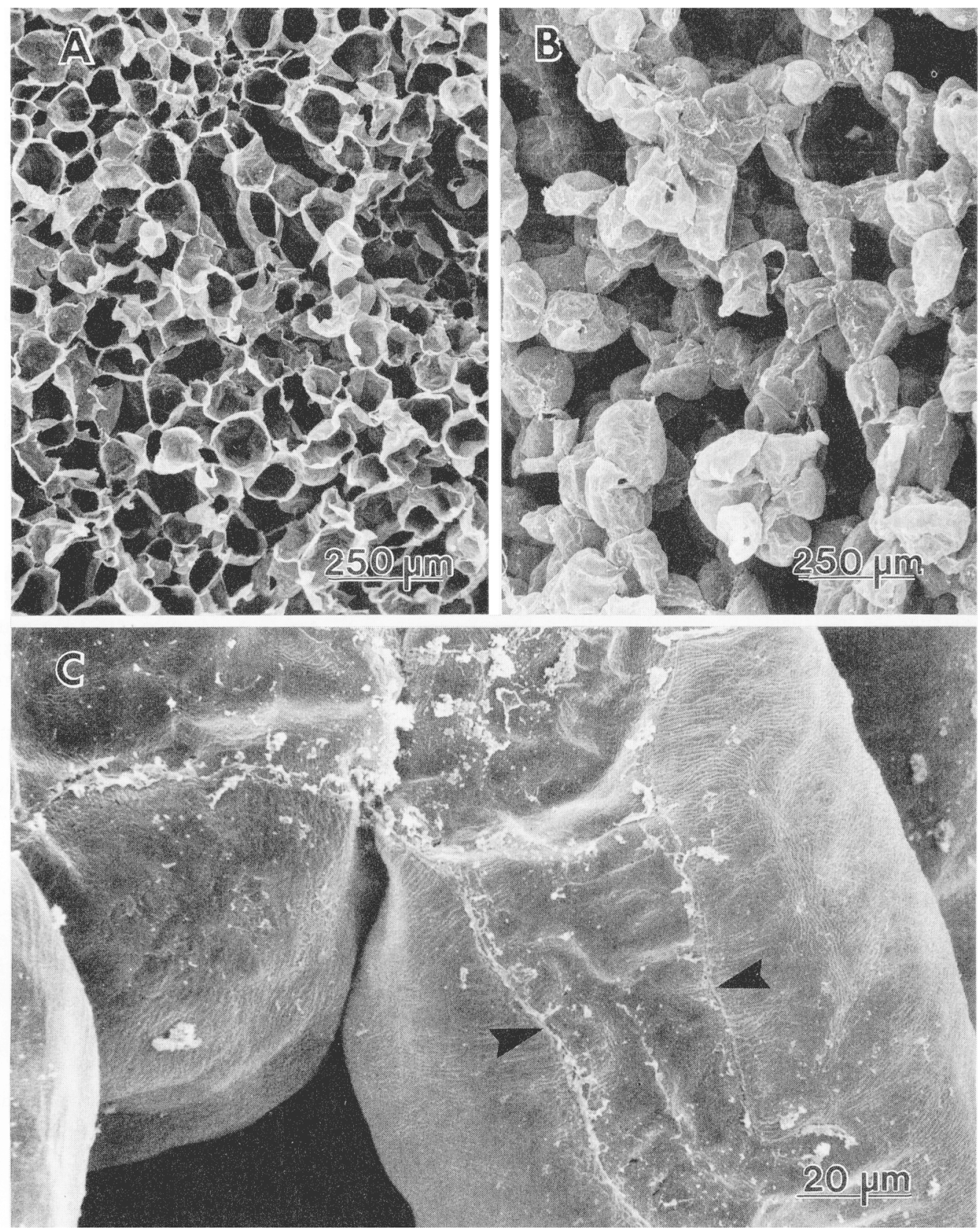

Fig. 8. Scanning electron micrographs of the surface of fractured apple tissue cylinders. Cylinders of tissue from Ca-treated fruit having high tensile strength (A) fractured through cells due to strong cell cohesiveness. Cylinders of tissue from untreated fruit having low tensile strength separated between cells (B) due to poor cell cohesive strength. A study of the region of cell-to-cell contact (arrows) from untreated fruit (C) revealed that cell separation occurred at the middle lamella with little or no tearing.

between treated and untreated fruit. After 6 months of storage, tissue from Ca-treated fruit generally were sheared through cells (Fig. 8A). In contrast, control fruit having low tensile strength tended to separate between cells (Fig. 8 B and C). Cell collapse was a common problem with the control samples. This condition may have been aggravated by stress created while performing tension tests or by desiccation before fixation. An enlarged view of cells from the control fruit shows that cell separation at the middle lamella occurred with little or no tearing (Fig. 8C).

In summary, softening in 'Golden Delicious' apple was characterized by distinct changes in composition and structure in cortical cell walls. These changes occurred predominantly in the middle lamellar region and resulted in a loss of cell cohesive strength and textural quality. Calcium preserved structural integrity of the cell wall and maintained cell cohesiveness. Although $\mathrm{Ca}$ infiltration treatments delayed softening, the fruit often did not infiltrate uniformly. This led to fruit mottling (nonuniform chlorophyll breakdown) and some localized regions of salt injury as described by Johnson (1979). The use of SEM in conjunction with textural studies provided a valuable technique for direct comparisons of physical and structural changes associated with softening in apple fruit. 


\section{Literature Cited}

Ahmed, A.E. and J.M. Labavitch. 1977. A simplified method for accurate determination of cell wall uronide content. J. Food Biochem. $1: 361-365$

Ahmed, A.E. and J.M. Labavitch. 1980. Cell wall metabolism in ripening fruit. Plant Physiol. 65:1009-1013.

Albersheim, P., D.J. Nevins, P.D. English, and A. Karr. 1967. A method for the analysis of sugars in plant cell-wall polysaccharides by gas-liquid chromatography. Carbohydrate Res. 5:340-345.

Bartley, I.M. 1974. b-Galactosidase activity in ripening apples. Photochemistry 13:2107-211 1 .

Ben-Arie R. and N. Kislev. 1979. Ultrastructural changes in the cell walls of ripening apple and pear fruit. Plant Physiol. 64: 197-202.

Betts, H.A. and W.J. Bramlage. 1977. Uptake of calcium by apples from postharvest dips in calcium chloride solutions. J. Amer. Soc. Hort. Sci. 102:785-788

Blakeney, A. B., P.J. Harris, R.J. Henry, and B.A. Stone. 1983. A simple and rapid preparation of alditol acetates for monosaccharide . analysis. Carbohydrate Res. 113:291-299.

Blumenkrantz, N. and G. Asboe-Hansen. 1973. New method for quantitative determination of uronic acids. Anal. Biochem. 54:484-489.

Brady, C.J. 1987. Fruit ripening. Annu. Rev. Plant Physiol. 37:155178.

Buescher, R.W. and G.E. Hobson. 1982. Role of calcium and chelating agents in regulating the degradation of tomato fruit tissue by polygalacturonase. J. Food Biochem. 6:147-160.

Conway, W.S. and C.E. Sams. 1984. Possible mechanisms by which postharvest calcium treatment reduces decay in apples (Malus domestics, inoculation with Penicillium expansum). Phytopathology 74:208-210.

Dey, P.M. and K. Brinson. 1984. Plant cell-walls. Adv. Carbohydrate Chem. Biochem. 42:265-382.

Diehl, K.C. and D.D. Hamann. 1979. Relationships between sensory profile parameters and fundamental mechanical parameters for raw potatoes, melons and apples. J. Texture Studies 10:401-420.

Ferguson, I.B. 1984. Calcium in plant senescence and fruit ripening. Plant Cell Env. 7:477-489.

Ferguson, I. B., M.S. Reid, and M. Prasad. 1979. Calcium analysis and the prediction of bitter pit in apple fruit. New Zealand. J. Agr. Res. 22:485-490.

Fry, S.C. 1986. Cross-linking of matrix polymers in the growing cell walls of angiosperms. Annu, Rev. Plant Physiol. 37: 165-186.

Fuller, M.M. 1976. The ultrastructure of the outer tissues of coldstored apple fruits of high and low calcium content in relation to cell breakdown. Ann. Applied Biol. 83 :299-304.
Glenn, G. M., A.S.N. Reddy, and B.W. Poovaiah. 1988. Effect of calcium on cell wall structure, protein phosphorylation and protein profile in senescing apples. Plant Cell Physiol. 29:565-572.

Grant, G. T., E.R. Morris, D.A. Rees, P.J.C. Smith, and D. Thorn. 1973. Biological interactions between polysaccharides and diva lent cations: the egg-box model. Federation of Biochem. Sot. Let. 32:195198.

Johnson, D.S. 1979. New techniques in the post-harvest treatment of apple fruits with calcium salts. Commun. Soil Sci. Plant Anal. 10:373382.

Kato, Y. and D.J. Nevins. 1984. Enzymic dissociation of Zea shoot cell wall polysaccharides I. preliminary characterization of the waterinsoluble fraction of Zea shoot cell walls. Plant Physiol. 75 :740744.

Knee, M. 1973. Polysaccharide changes in cell walls of ripening apples. Photochemistry 12:1543-1549.

Mahanty, H.K. and B.A. Fineran. 1975. The effects of calcium on the ultrastructure of Cox's Orange apples with reference to bitter pit disorder. Austral. J. Bet. 23:55-65.

Mason, J.L. 1976. Calcium concentration and firmness of stored 'McIntosh' apples increased by calcium chloride solution plus thickener. HortScience 11:504-505.

Mohsenin, N.N. 1970. Physical properties of plant and animal materials. Gordon and Breach Science Publ., New York.

Poovaiah, B.W. and G.A. Moulton. 1982. Vacuum/pressure infiltration process for fresh produce. U.S. Patent 4,331,691.

Poovaiah, B.W. and A.S.N. Reddy. 1987. Calcium messenger system in plants. Crit. Rev, Plant Sci. 6:47-104.

Ridgeway, R.L. 1986. Flat, adherent, well-contrasted semithin plastic sections for light microscopy. Stain Technol. 61:253-255.

Sams, C.E. and W.S. Conway. 1984. Effect of calcium infiltration on ethylene production, respiration rate, soluble polyuronide content, and quality of 'Golden Delicious' apple fruit. J. Amer. Soc. Hort. Sci. 109:53-57.

Scott, K.J. and R.B.H. Wills. 1977. Vacuum infiltration of calcium chloride: a method for reducing bitter pit and senescence of apples during storage at ambient temperatures. HortScience 12:71-72.

Takavoli, M. and R.C. Wiley. 1968. Relation of trimethylsilyl derivatives of fruit tissue polysaccharides to apple texture. Proc. Amer. Soc. Hort. Sci. 92:780-787.

Topping, A.J. 1981. A recording laboratory penetrometer for fruit. J. Agr. Eng. Res. 26:179-183.

Updegraff, D.M. 1969. Semimicro determination of cellulose in biological materials. Anal. Biochem. 32:420-424. 